\title{
Practical Relevance as an Issue for Contemporary Border Studies
}

\author{
Serghei Golunov \\ Visiting Professor, Slavic-Eurasian Research Center, Hokkaido University (Japan) \\ Address: Nishi 7, Kita 9, Kita-ku, Sapporo, 060-0809, Japan \\ E-mail: sgolunov@mail.ru
}

\begin{abstract}
Although border issues are a matter of importance for a large number of people, contemporary Border Studies (dominated by the intertwining of post-modernist, constructivist, and critical approaches) is little preoccupied with finding viable practical solutions, focusing instead on conceptualising the essence of borders and border processes. Meanwhile, previous Border Studies was a practically-oriented discipline focused on helping practitioners delimit borders, and to find an optimal balance between protecting borders against unwanted crossborder flows and fostering desirable cross-border interactions. The article examines the widespread theoretical approaches to studying borders in the light of their practical relevance, and discusses what can be done in order to make Border Studies more capable of generating viable practical solutions. Despite the fact that mainstream Border Studies is currently not much preoccupied with bridging theory with practice, I argue that both contemporary and older approaches have significant practical potential which could be especially helpful in solving delimitation problems, increasing efficiency of cross-border cooperation, better balancing the priorities of strengthening border security and fostering cross-border interaction, cross-border region building, managing cross-border conflicts and mitigating alarmist perceptions of the Other, fighting border-related injustices and human rights violations, etc. In addition, I suggest that drawing new ideas from Management Studies and Communication Studies could be promising ways of making Border Studies more practically relevant.
\end{abstract}

Keywords: Border Studies, border security, constructivism, critical studies, cross-border cooperation, post-modernism, practice, pragmatism

Borders have great importance for a large number of people. While for some people borders are shields or fences protecting them against violence and social disorganization, for others, they are first and foremost barriers impeding mobility, human contact, and economic development. There are many cases when toughening or liberalising border regimes becomes a life-and-death issue, and probably many more cases when it crucially affects people's prosperity. Border issues are often so urgent that even a small delay in solving them could adversely affect many people.

However, it is oftentimes not easy for Border Studies scholars to make valuable contributions to solving practical issues. The problem is that borders and border-related processes are complicated and multidimensional; studying them requires interdisciplinary approaches drawing ideas not only from geography, but also from political science, sociology, economics, history, philosophy, and other disciplines. It is still not quite clear what borders are and how they work; thus, in many cases it is difficult to advise on what should

\footnotetext{
(C) Serghei Golunov, 2014

(c) Centre for Fundamental Sociology, 2014
} 
be done with them. It is therefore understandable why contemporary Border Studies are so preoccupied with conceptualizing the essence of borders and border processes, taking into account recent social sciences' achievements. Nevertheless, it is regrettable that contemporary theorizing on borders rarely has any evident practical implications that could bring some improvement in the foreseeable future. It looks somewhat useful, therefore, to employ "a pragmatist maxim" (sometimes called "pragmatist razor"), positing that an idea should be evaluated by its practical bearings (Peirce, 1992: 132), for reviewing contemporary Border Studies theories in order to evaluate those theories' practical implications.

Are there ways to bring back practical relevance to contemporary Border Studies? To what extent can the existing approaches to research on borders be made practically relevant? What other approaches can be potentially employed for this purpose? These are the key questions to be considered in this article. Initially, I consider those conceptual approaches of studying border issues that prevailed until the 1990s. Secondly, I discuss practical implications of the contemporary mainstream approaches, viz. post-modernism, constructivism, and critical Border Studies. Finally, I examine how some other academic approaches that are currently used or can be employed from other disciplines that could make research on borders potentially practically relevant.

\section{Traditional Approaches}

At the beginning of its history, Border Studies was a discipline close to geopolitics (justifying territorial expansion by national interests and suggesting where a stronger power should draw its borders), and at the same time, was an applied discipline of the findings which were designed to solve delimitation, demarcation, and other relevant practical border-related issues. The primary stress was laid on the art of drawing borders in the way that could allow making them better defensible from invasion by an enemy and less prone to conflicts caused by incorrect political delimitation. Special attention was paid to the delimitations between colonial empires, as such borders were oftentimes vague. The public address of Lord Curzon, commonly considered as the pioneering work in the field of Border Studies, is mostly the classification of the existing types of borders, and analysing their strengths and weaknesses with a strong emphasis of the interests of the British Empire (Lord Curzon, 1907).

One of the key lines of discussion concerned "natural borders," i.e., the borders defined by natural obstacles-rivers, mountain ridges, deserts, woodlands, etc. The first Border Studies researchers disagreed on what is the most important function of such borders and what kind of natural borders were the best. While Lord Curzon (1907) preferred mountain ridges and deserts and Tomas Holdich (1916: 149-156) preferred mountain ridges as defense lines, finding river borders too vulnerable and unstable (as river beds can change), other authors, such as Lionel Lyde (1915), on the contrary, preferred rivers which, while dividing countries politically, didn't hinder much interaction between such countries. Other kinds of borders promoted by geographers of that period including Karl 
Haushofer (1939), emphasized that national borders should be brought into compliance with ethnic borders that were considered a "restoration of historical justice."

While some ideas of that time are considered outdated now, other ideas on how borders are better to be demarcated are still useful for politicians and other practitioners involved in negotiations on borders and in settling border disputes. It is also important that early Border Studies researchers (Curzon, 1907; Fawcett, 1918) had already formulated the key and still highly relevant practical dilemma of the discipline, i.e., the dilemma between ensuring border security and allowing a border to be penetrable enough for useful crossborder interaction. While toughening border control better protects a country against illicit and "unwanted" flows (smugglers, illegal immigrants, hostile militants, etc.), it also hinders legal and "desirable" flows (tourists, cross-border entrepreneurs, or high-skilled workers). On the other hand, relaxed border control creates more favourable conditions for legal and "desirable" flows but also opens a wider range of opportunities for lawbreakers. Yet, later research (especially on the U.S.-Mexico border) demonstrated that the influence of a tightened border regime on illicit cross-border flows is mixed and controversial: tough border policies oftentimes itself create the ground for smuggling and other illicit cross-border activities (increasing their profitability dramatically) and causes the emergence of skilled and well-organized criminal groups, specializing in exploiting vulnerabilities of border control. All of these conditions can lead to the escalation of competition between those who protect borders and those who try to bypass border control (Andreas, 1999, 2009).

Nevertheless, after the end of World War II, with the subsequent collapse of the colonial system and the entrenchment of the principle of inviolability of borders in international law, a large part of those practical ideas that were advocated by early Border Studies scholars became anachronistic. There was now very little room for arbitrary and one-sided expansion (especially for colonial expansion) and choosing favorable borders, so even strong countries had to deal with existing borders however "bad" they were. The interest of borders as barriers against military invasion also reduced noticeably, as it was admitted that no border fortification lines were efficient against modern weapons. Because of this reason, borders didn't become an important topic for nascent International Relations Theory, particularly for IRT's first dominant tradition of political realism (Aron, 1984: 90; Herz, 1957: 482; Wolfers, 1962: 97).

It is then not surprising that post-war Border Studies paid less attention to resolving practical issues than before, focusing instead largely on determining the essence of borders, on classifying them, on relationships between borders and borderlands or between borders, and those state institutions that shape them. More specifically, different scholars focused on sorting borders or cross-border flows by various criteria (House, 1982; Martinez, 19941); a few concentrated on determining the range of functions that borders have,

1. The classification offered in the latter work is the most known. Oscar Martinez divided borders into four kinds; alienation borders (characterized by closeness and alienated relations between neighboring countries), coexistence borders (where cross-border cooperation develops only to a limited extent), interdependence borders (where cross-border cooperation rests on evident asymmetry between adjacent countries' economic con- 
several focused on the process of their historical evolution (Foucher, 1988), some investigated the conceptualization of borders as "power projections" of state institutions behind them (Foucher, 1988: 22; Prescott, 1965: 76), some on interconditionality or borders and borderlands (Prescott, 1978), and others researched the topic of border-related actors and on the ways these actors interacted (House, 1982; Martinez, 1994). All of these issues still had their implicit practical relevance; classifications of borders allowed the revealing of their strengths and weaknesses, classifications of cross-border flows could allow making border policies more sensitive to various kinds of such flows, investigating evolution of borders could contribute to better understanding of their current issues and help to make better prognoses, examining interrelations between borders and surrounding territories could help to better planning of these territories' development, and studying borders as projections of institutional power could help to understand how such institutions should be reformed to improve border policies.

All of this does not mean that more explicitly applied issues were not considered by post-war Border Studies scholars. While delimitation and demarcation issues were now given somewhat less importance, the focus of practically oriented research shifted towards studying governance, planning, economic, environmental issues, issues of borderland regions, and especially cross-border cooperation. These issues receiving greater attention were largely stimulated by European regional initiatives since the 1950s. In this light, borders were oftentimes seen as an evil that posed economic and environmental damage, distorted cross-border ties (Bröker, 1984; Hansen, 1981; Petras, 1996), and put border regions in economically-disadvantageous marginal positions (Giersch, 1949), often aggravated by the over-centralization of governance and by the poor consideration of the borderland regions' interests by their central authorities (Stoddard, 2002: 40). To ameliorate these problems, the removal of unnecessary border barriers, better planning of cross-border projects, and granting more powers to borderland regions were considered to be the most typical remedies.

Generally, post-war Border Studies evolved in a rather typical direction from a largely empirical and applied discipline towards more abstract conceptualizations. It was not only the accumulation of information but also the changing post-war international relations context, discouraging "too creative" approaches to remaking borders, that pushed researchers in this direction. Still, many conceptual findings could be easily connected with practice and, finally, the development of cross-border cooperation provided Border Studies scholars with a large field of practically-oriented research.

\section{Contemporary Mainstream Approaches}

In the 1990-200os, a major revolution in Border Studies occurred. The research on borders was incorporated into mainstream social science approaches that made the subject increasingly popular and led to dramatic growth in the number of Border Studies

ditions and resources available for cross-border re-distribution), and integration borders (where no significant restrictions impede close cross-border cooperation). 
academic publications in the 2ooos. This revolution was overwhelmingly post-positivist: while investigation of objective border-related regularities remained a marginal trend of research, the subjectivity of borders was emphasized in various ways. According to my classification (that, of course, is not the only possible one), the main directions of post-positivist research have been post-modernism, constructivism, and critical studies, though in practice, these approaches are oftentimes intertwined and used in combination. For the sake of greater clarity, let us consider these approaches separately, considering the issues of their practical relevance among other matters.

\section{Post-modernism}

Proponents of this approach challenge the notion of contemporary political borders' rigidness, immobility, and singularity, emphasizing their flexibility, mobility, and plurality.

According to a radical version of this approach, national borders are dying away in the conditions of globalization (Ohmae, 1995) or, at least, losing their importance inasmuch as states can not efficiently control accelerated flows of people and goods at their borders. Thus, such states have to switch increasingly to more deterritorialized forms of control over flows, thus making borders largely irrelevant (Bigo, Guild, 2005). Moderate advocates of a post-modernist approach towards borders are more cautious, arguing that national borders still do matter but that they are less stable (the processes of deterritorialization are followed by reterritorialization, while debordering is followed by rebordering), more intensively multiplying and vacillating, and becoming more selective towards the various categories of people crossing them (Albert, 1999; Balibar, 2002: 88-90).

As does any other approach, post-modernist insights into border issues have typical vulnerabilities. First, there is no convincing proof that the vanishing of national borders is becoming a global trend; while some countries (first of all, the EU member states) erased some borders, other borders (including external borders of the EU) are being fortified instead. Moreover, construction of border fences, reminiscent of ancient fortification practices, is becoming increasingly widespread in various areas of the world (Golunov, 2014).

Secondly, it is not easy to prove that contemporary borders really lose their importance and efficiency in comparison to the past. Though present border control is generally not very efficient, it was also not so efficient in the past. At the same time, now border control becomes generally more comprehensive and sophisticated than in previous eras (Andreas, 2009: 143; O’Dowd, 2010).

Thirdly, most borders can be considered both via the lens of the "traditional" imaginary (emphasizing efficient territorial control practices by respective states, the static character of borders and the fact that spatial movement of people across "hard" borders is still carefully limited), and via the lens of post-modernist imaginary (emphasizing the intensity of cross-border flows, vulnerabilities, and deterritorialized practices of border control, essential differences in border regimes for various categories of entrants, cross- 
border spaces and initiatives, etc.) (Golunov, 2012: 77-79). In this case, the argument that "traditional" state-centric imaginary is "old" and "outdated," while "deterritorialized" imaginary is "up-to-date" (Bigo, 2008: 105; Vaughan-Williams, 2009: 165) looks more stereotypical than a valid reason for preferring the second sort of imaginaries over the first one.

Fourthly, while there are indeed numerous invisible and flexible borders that can multiply and vacillate, the tangible and immobile national border still remains, at least, one of the most important types of borders that seriously influences the fates of a vast number of people. There is a danger that more important national borders can be neglected in favor of numerous less important but "more fashionable" virtual borders.

Lastly, but not least, if not a strategic "above" or a "God's eye view" but a traveller's "horizontal" perspective of looking to a border is taken as a reference point, one can argue that for such a traveller, the "hard" national border still does matter virtually as much as it did earlier. Indeed, such a border still confines precisely the territorial limits of a traveller's movement and a trespasser who ignores this "hard fact," while relying too much on the assumption that national borders lose their importance, seriously risks being apprehended and punished (Golunov, 2013: 935).

The most important domain of applying post-modernist Border Studies to practically relevant issues is, apparently, cross-border region building. Indeed, in many cases, post-modernist Border Studies offers much in terms of making new cross-border regions with new borders, creating overlapping spaces in which partially coinciding and partially divergent ranges of actors can be involved, or reducing the role of formal territorial limits in cross-border planning. It is noteworthy that the current map of European cross-border regions (Association of European Border Regions, n.d.), dominated by overlapping entities $^{2}$, is strikingly different from the "traditional" political map of Europe on which all territorial entities are clearly delimited. Such flexibility allows participants of cross-border cooperation initiatives to more easily overcome border barriers and adjust specific cooperation projects to various territorial frameworks to ensure these projects' efficiency.

The problem here is that such approaches work much better in areas where national borders are weak, and evidently worse in cases when national borders are "hard" and persistent. For example, there were some conceptual proposals on how to "post-modernize" the EU's external borders, including its relevant borders with the Kaliningrad province. Jan Zelionka suggested to make the EU's "hard" border fuzzy, resembling "the borders of a neo-medieval Europe rather than the borders of a Westphalian Europe." According to Zelionka, in the new borderlands of the "maze Europe," "different legal, economic, security and cultural spaces are likely to be bound separately, cross-border multiple cooperation will nourish, and the inside/outside divide will be blurred" (Zelionka, 2001: 518). Pertti Joenniemi suggested applying a similar idea both to the Kaliningrad province

2. For instance, the Kaliningrad province participates in five cross-border regions; the Baltic (with Danish, Lithuanian, and Swedish partners), Łyna-Ława (with Polish partners), the Neman (with Belarusian, Lithuanian, and Polish partners), the Saule (with Latvian and Lithuanian partners), and the Šešule (with Lithuanian and Polish partners) (Ministry of Foreign Affairs of the Russian Federation, 2013). 
(Joenniemi, 2000) and to the regions of the Northern Dimension (Joenniemi, 2008: 172), turning them into "neo-medieval" zones of overlapping spaces. Subsequent developments, however, demonstrated that geopolitical divides and security-related alarmism prevents the blurring of the EU's "hard" border from both of its sides; while the EU was not eager to weaken its immigration barrier and its Baltic member states to give Russia economic or other leverages for influence, Russia was afraid of separatism of its borderland regions in cooperating "too closely" with their EU counterparts.

Another problem with "post-modernization" of borders should be also taken into account. When relations between neighboring countries are normal and the discourse of cooperation prevails, officials stress that borders are barriers only for criminals but not for law-abiding people, that ongoing cooperation contributes to the erasing of borders, and so on. In such cases, "post-modernization" trends are overemphasized while the remaining pervasiveness of visa, customs, and border-related barriers can be downplayed in official discourses. In such cases, the "post-modernization" trend makes a difference more in official rhetoric than in practice of those who are involved in various crossborder contacts.

Nevertheless, post-modernist Border Studies can be considered as a critically important tool for building cross-border spaces of various kinds. This tool, however, should not be perceived as a panacea for overcoming border barriers and its limitations, and pitfalls should be fully taken into account.

\section{Constructivism}

Constructivist Border Studies, which gained significant popularity in 1990 a after the seminal works of Anssi Paasi (1996), emphasize the importance of border-related norms, meanings, and representations. According to Étienne Balibar, borders are polysemic, as they have different meanings for different people (Balibar, 2002: 81-82). In accordance with constructivist Border Studies, the "material dimension" of borders does not matter per se as even the most impressive border walls only matter inasmuch as and until when they are given the sense of important defensive barriers. The Berlin wall can serve a good example in this case. At the same time, both material and discursive practices that support such norms and meanings giving them importance also are important (Morehouse, 2006: 33; Paasi, 1999: 670).

A distinct line of constructivist Border Studies corresponds to the theory of securitization as proposed by the Copenhagen School of Security Studies. According to this theory, border-related problems are construed as security issues (meaning problems requiring extraordinary and urgent solutions). Making these issues into matters of security is done via securitization moves addressed to significant audiences that could either accept or reject such moves (Buzan et al., 1998: 25-32). The phenomenon of framing some borderrelated problems (especially immigration) as border security issues was considered by some authors without employing the conceptual framework of the Copenhagen school 
(Andreas, 1999; Wonders, 2006: 83). In some cases (Bigo, 2014; Rumford, 2013; Vukov, Sheller, 2013) the securitization framework, however, was employed explicitly.

At the present, constructivist Border Studies do not appear to be preoccupied with the uses of their findings. Firstly, it looks like researchers applying a constructivist approach pay more attention to purely "imaginary" borders (such as intergroup) than to the borders having strong material dimensions. As in the aforementioned case of some postmodernist scholars, there is the risk that the issues as relating to national borders could be put aside as no longer "fashionable," regardless of the number of people these topics affect. Secondly, deconstruction is oftentimes not the best way for solving practical issues inasmuch that it doesn't offer many positive solutions if taken alone. It is not surprising that most works emphasizing an constructivist approach to Border Studies issues do not appear to be practically oriented, at least explicitly.

Nevertheless, constructivist Border Studies have potentially significant practical implications in terms of ameliorating cross-border relations and desecuritizing excessively alarmist border policies. In this light, it is important that the same borders oftentimes can be represented both in (more) alarmist and in non- or less-alarmist ways. In the 1990 os and 20oos, the Russian-Kazakhstan border (the longest continuous border in the world) was frequently pointed to in connection to various threats to Russian national security through issues of trafficking in heroin, large-scale smuggling of Chinese goods, illegal immigration, transborder extremism, etc. Occasionally, the idea to introduce a visa regime for the citizens of Kazakhstan, or even to construct a border fence, were proposed by Russian politicians. Yet, another representation of the Russia-Kazakhstan border emphasized the friendly character of relations between Russia and Kazakhstan, the profits of integration between the two countries, but also the inefficiency of unilateral border protection against illegal transborder flows finally prevailed (in particular, border guards and customs officers are typically able to reveal just up to several percent of drugs smuggled via checkpoints) (Golunov, 2008). As a result, customs control at the RussianKazakhstan border has been abolished since July 1, 2011. The U.S.-Mexico border can be considered polemically; while until the 1980s, illegal immigration and other issues were not prioritized as national security threats. The "war on drugs" in the 1980s and anti-immigrant operations in the 1990 s and the 2000 s led to the building of sophisticated fences, the militarization of border protection, the criminalization of illegal immigration, the escalation of confrontations between illegal immigrants and growing numbers of borderprotection officers, and increasingly sophisticated and organized criminal groups, etc. (Andreas, 2009).

Taking this into account, constructivist Border Studies scholars can contribute to deconstructing negative and alarmist perceptions and representations of the Other, thus undermining the reason why it should be separated by a "hard" border. In terms of the Copenhagen School, constructivist scholars can elaborate and themselves undertake "desecuritization moves" (more specifically, deconstructing alarmist border-related stereotypes by proving their irrelevance and emphasizing, if expedient, the benefits of bilateral cooperation in various fields, including security) and that, if accepted by significant 
audiences, could also lead to more relaxed control over routine cross-border movement of people and goods. After deconstructing those perceptions and meanings that underlie "hard" and (if the mentioned classification of Oscar Martinez is employed) "alienation" borders, one can try to reconstruct more friendly and open borders by contributing to the elaboration of more cooperative discourses and common agendas.

However, if a "hard" border is established or securitized as a result of a very serious ethnic or other conflict, a more cautious approach may be needed in order to prevent an uncontrolled and spontaneous reconstruction of some other material or imaginary "alienation intergroup borders," allowing participants of such conflicts to feel protected. Thus, the most appropriate solution in many of such cases could be not in attempting to erase such a border, but to find an optimal balance between fostering cross-border communication and preserving some type of barrier that signifies security for those who are behind it (Henrikson, 2000). It is sometimes argued, for example, that maintaining limited, manageable, and gradually intensifying communication across both physical and virtual intergroup borders is crucially important. This is evident with such conflicts as the one in Cyprus (Diez, 2003), where in the 1970s, a clear separation line ultimately replaced numerous virtual division lines between conflicting communities throughout the island. In such cases, constructivist Border Studies scholars can potentially contribute to peaceful solutions and elaborations to less ambitious agendas (i.e., oriented to solving small local problems), but over time, to more comprehensive common cross-border discourses, and cooperation agendas.

\section{Critical Border Studies}

While being applied to Border Studies shortly after post-modernism and constructivism, Critical Studies has become the most dynamically growing trend of mainstream research on borders since 2000. Critical Border Studies considers border issues in terms of power, ordering, exclusion of the Other, injustice towards those who are excluded, and the increasing surveillance of cross-border travelers. Here is a non-exhaustive list of topics covered by Critical Border Studies:

- Making, maintaining, and reproducing exclusive borders in a threefold process of bordering (legitimization of location of a border), ordering (maintaining order), and othering (excluding the Other) (van Houtum et al., 2003; van Houtum, 2010).

- A "legal vacuum" in which travelers find themselves during border control and illegal immigrants find themselves in detention camps. In such situations, travelers and immigrants do not enjoy full-fledged rights, their movement is limited, and officials can make largely-arbitrary decisions on their deportation while possibilities to appeal against such decisions are usually very limited. Some scholars (Salter, 2008; van Houtum, 2010: 970-71; Vaughan-Williams, 2009), tried to apply Giorgio Agamben's concepts of "state of exception," "bare life," and "homo sacer" to such situations, denoting a person who finds himself in the state of exception, 
deprived of his/her rights, and reduced to his/her biological existence (Agamben, 1998; Agamben, 2005). Others, however, find the application of these terms to border issues exaggerated, arguing that Agamben's terms should be applied only to the situations when exceptional violence (detention or arbitrary killing) takes place, while in the respect to the above-mentioned border-related or immigration-related situations, some other terms (such as "grey spaces" or "liminal legality") are more suitable (Jones, 2012: 691).

- Surveillance and sorting of cross-border travelers. Conceptualizing this issue typically rests on both critical and post-modernist insights. On the one hand, it concerns the increasing and largely non-accountable power of a state to monitor the cross-border movement of people using their biometrical information. On the other hand, it posits, that in terms of security, physical national borders lose their importance in comparison to imaginary borders that qualify or disqualify a person on the basis of his/her biometrics and other personal characteristics, such as citizenship, profession etc. (Lyon, 2003; Bigo, 2005b; Zureik, Salter, 2005). It is argued that such surveillance and sorting is proactive, and a decision on a person's (non)admission is usually made long before a person arrives at a national border he/she intends to cross (Bigo, 2005). The majority of relevant works focus on analyzing how the surveillance and sorting machinery operates; what steps does this process include, what criteria are used for sorting, what is the role of poorlygrounded suspicion in this process, etc. There is also a growing number of works taking into consideration the perspective of those travelers who are the focus of surveillance and sorting practices (Amoore, 2013; Salter, 2008; Salter, 2013), and also the perspective of officers involved in implementing these practices (Aas, 2011; Bigo, 2014; Pratt, 2010).

- The appropriateness of border and immigration control versus the fundamental principles of liberalism and social justice. Some scholars argue that border and immigration control is at odds with liberal values as it excludes those who wish to join a community proclaiming its democratic, open, and non-discriminatory character. It also contradicts the principle of social justice as such exclusions that is typically made on the basis of wealth, citizenship, and (indirectly) ethnicity, thus disqualifying poor people and inhabitants of third-world countries, while affirming rich people (Balibar, 2004; Bigo, Guild 2005; Kymlicka, 2001; Steiner, 2001). Strict border and immigration controls turns wealthy Western societies into "gated communities," closed to poor and disadvantaged immigrants, who in some cases trying to change their fates, risk their lives and sometimes perish while trying to cross borders in dangerous areas to enter rich countries illegally (van Houtum, 2010).

- Borderwork as a set of societal activities on making or breaking borders (Rumford, 2008, 2013). This concept demonstrates that not only a state can create and maintain borders or tighten/relax border regimes, but non-governmental actors, including ordinary citizens, can contribute to it (i.e., helping immigrants, lobby- 
ing for stricter immigration policies, or even creating volunteer border patrols as it has done at the U.S.-Mexico border).

It seems that at least several following vulnerabilities are typical (though not necessarily intrinsic) for contemporary critical Border Studies. Firstly, most researchers confine themselves to severely criticizing existing policies while not proposing any viable solutions. Meanwhile, practitioners should act in some way, oftentimes choosing not from "good" and "bad," but from several just "bad" policy options, any of which can be harshly criticized. Thus, these practitioners have a good reason to ignore destructive criticisms when viable alternative solutions are not proposed. Secondly, as well as other mainstream approaches, Critical Border Studies focuses mainly on "grand issues," usually (though not always) considering them from the "above" (or "God's eye view") perspective, and much more rarely from the "horizontal perspective," taking the border-crossers' position towards borders as a reference point. As a result, a large part of those mundane practical issues (such as problems of customs control, extortion, or queues at borders, etc.) that matter for many millions of cross-border travelers are neglected. In cases when the perspective of border-crossers is taken into account, they are typically represented as helpless objects of coercive or manipulative practices without considering their chances to defend their interests, either by themselves or with the help of influential allies.

Thirdly, critical Border Studies usually takes an uncompromising stance towards the existing realities, harshly criticizing advocates of tough immigration policies. Meanwhile, the political influence of proponents of the tough approach is growing; it is oftentimes very difficult to change border policy without taking into account such specific interests. While one cannot fully exclude that border policies could become essentially more fair towards immigrants and travelers (it probably could happen, not soon, but in some distant future). Meanwhile, it is also important to contribute to the improvements for those who have to overcome border barriers as soon as possible, even if such improvements are initially half-way and small. Achieving such improvements now probably requires dialogue with opponents of liberal immigration policies, and finding ways how to achieve compromises with them.

In terms of its practical relevance, Critical Border Studies is a useful tool for diagnosing such problems as arbitrary power that consular and border guard officers have over ordinary border-crossers, making decisions on foreigners' non-admission on the basis of poorly-grounded suspicions, the lack of those legal rights that would allow foreign entrants and immigrants efficiently defending themselves against unjustified decisions about non-admission or deportation, violations of the rights of those who are subjected to uncontrolled surveillance, or to ill-treatment by officers, or in detention camps.

However, as already mentioned, critical Border Studies scholars usually refrain from proposing well-elaborated and realistic recommendations. When recommendations are proposed, they look either too vague or unrealistic in most cases. Trying to solve the problem of "unjust border control," some scholars proposed to abolish it or reduce it to a minimum (Steiner, 2001: 80). Some scholars advocate that "wealthy countries can only 
restrict admissions if they share their wealth with poorer countries" (Kymlicka, 20o1: 271), and some suggest to make border control democratic with the participation of immigrants (Balibar, 2004: 117). Unfortunately, the authors of all of these proposals do not seriously try to anticipate or to prevent evident criticism. In the first case, it is not clear how to prevent social disorganization of communities affected by massive immigration; in the second case, the problem lies in how to make monetary donations to the poorest countries efficient; in the third case, the question remains how to reconcile contradicting interests of immigrants and alarmist-minded local inhabitants while ensuring the efficiency of the democratic decision-making process. (Robert Latham's idea that trusted NGOs could become intermediaries between immigrants and destination-countries, (Latham, 2010), may deserve more serious attention if the questions of how to avoid turning these NGOs into inefficient bureaucratic structures overloaded by huge number of requests and, even more important, of how such NGOs could be really useful in revealing ineligible immigrants, are responded to persuasively).

It seems that Critical Border Studies potentially could make a greater contribution to solving practically relevant problems. Whereas critical scholars already have done much in terms of criticizing suspicion-based algorithms of decision-making in allowing the entry of applicants used by consulates and border guards to deny entrance, they could do more in terms of proposing ways to improve such algorithms and to diminish the grounds of human rights violations. Are there realistic ways to better protect the rights of those who are denied entry without a reasonable basis? Could scholars help practitioners make risk-analysis algorithms that could be applied towards visa applicants and entrants and that are more sensitive towards specific cases and less over-reliant on such criteria as financial solvency ${ }^{3}$, the region of an applicant's birth ${ }^{4}$, and the straightness of the route by which a traveller arrives at a destination point?

Another possible contribution of Critical Border Studies is to conceptualize the ways of resistance to the unjust sorting and surveillance system, and the enforcement of this system to increasingly respect border-crossers' interests and rights. Contemporary mainstream Border Studies are evidently sympathetic towards immigrant protest movements and such radical non-governmental initiatives as the NoBorder network ${ }^{6}$, and sometimes analyze individual cases of protest actions or attempts to disseminate information via alternative "tactical media" (Vukov, Sheller, 2013). However, I have yet failed to identify any well-elaborated conceptual ideas in major relevant academic publications of possible

3. Russian teachers (including university teachers) or doctors, who are typically underpaid and earn about the same as Russian low-qualified workers, are apparently treated by EU consular officers with much more suspicion than heavily compromised but solvent officials.

4. I heard several stories (including one story from a well-informed high-standing Russian provincial official) that give some reason to infer that EU consular officers sometimes use a birthplace as a substitute for the "politically incorrect" risk criterion of ethnicity, thus excluding those who was unlucky to be born in a wrong place.

5. There were many cases when EU member states' border guards denied entry to those non-EU travelers who travelled by suspiciously unusual routes. Actually, travelers could prefer such routes in attempting to save money (i.e., buying discounted multi-segment airline tickets).

6. See Noborder Network, n.d. 
courses of civic actions or other ways of resistance to the unjust order, and about specific and realistic demands that could be presented to those who control borders. Giorgio Agamben's passive resistance, viz. his refusal to enter the USA in order to disable biopolitical surveillance on him, though being praised by some scholars (Vaughan-Williams, 2009: 144), does not appear to be efficient if considered as the a way of prompting the system to change. Nevertheless, despite the (currently) Critical Border Studies inability to propose clear and efficient ways of resistance to border-related injustice, together with realistic demands on how to reduce such injustices, one cannot preclude that they will be able to propose such ways in the future.

\section{Other Approaches}

Of course, the range of already considered approaches is far from being exhaustive. There are many other approaches, probably most of which have some practical potential. Let me consider some of these approaches.

Within policy-oriented research, significant emphasis is made both on cross-border cooperation and on the increasing efficiency of border management. One of the key problems is solving the mentioned dilemma between border security and cross-border interactions. Since the 2000s, the concept of a "smart border," introduced by the U.S. and Canadian officials (Legislationline, 2001) and recently adopted by EU officials (Europa. eu, 2013), has become an important focus, not only for practitioners but also for scholars. The concept prioritizes both the strengthening of border security and fostering crossborder interactions achieved by very close cooperation between the adjacent countries in the fields of border security and immigration control, increasing the capacity of checkpoints, and by pre-screening some categories of people and vehicles crossing a border, together with reducing border inspections of them to a minimum. Both some "smart border" practices and the overall results of applying the concepts were very critically received by scholars, who argued that making the U.S._Canada border "smart" didn't help to prevent a serious decline in economic activities caused by toughening border security after September 11 (MacPherson et al., 2011), and also that "smart border" means privileging elite travelers and poorly controlled surveillance of over-border crossers (Côté-Boucher, 2008). Two more potential problems also are that an efficient "smart border" is very expensive (in the mid-20oos, the U.S.-Canada border security policy was much more expensive than the EU's (Brunet-Jailly, 2006)), and requires very close and stable cooperation between the participating countries. If such cooperation weakens, the efficiency can also seriously weaken. Still, some researchers propose recommendations on how to improve the existing "smart border" policies in terms of developing border infrastructure, reforming governmental agencies dealing with border security issues, strengthening bilateral cooperation between adjacent countries, etc. (Ackleson, 2009).

While the "smart border" concept prioritizes the interests of involved states and privileged border-crossers, voices of ordinarily law-abiding border-crossers are still poorly heard. Trying to make the theorizing on borders more practically oriented and to find 
out if there are some ways to make border-crossers' voices better heard, I proposed the pragmatist-dialogical approach (Golunov, 2012, 2013). This approach, on the one hand, emphasizes the aforementioned pragmatist maxima and anti-scepticism (something that should be proposed instead of criticized policies), and, on the other hand, focuses on dialogism (the approach that is often employed in combination with pragmatism (Baert, 2005)) for conceptualizing reciprocal communication between border-crossers and those who maintain "hard" borders. My ongoing research suggests that in some situations, some categories of border-crossers are able to make themselves heard mainly by organizing protest actions near checkpoints or in borderland towns, or by resorting to some powerful mediators (their state governments, politicians, journalists, etc.). Still, there are at least two important factors undermining the efficiency of the considered dialogue. Firstly, border-crossers are usually poorly organized, which reduces their capability for joint actions. Secondly, officials are much more politically powerful which gives them a wide range of opportunities to manipulate dialogues, to pressurize their opponents, or simply to avoid communication. Though these obstacles are not insuperable, further empirical research is needed to establish the extent to which border crossers can be heard as a result of their own efforts, and to suggest how to help border-crossers to organize better, and to amplify their voices.

Apart from dialogism and Organizational Communication Studies, some managerial approaches, such as studies of feedback, could be potentially useful for better conceptualizing the problem. The key problem of feedback by border-crossers to officials is in overloaded communication channels, specifically, consulates, immigration services, and customs services in many cases do not have sufficient staff to react to all complaints and suggestions. Another problem is that officials do not always want to deal with uncomfortable questions and complaints, and sometimes forward them to those who are complained about. Thus, the practically-oriented research on feedback by border-crossers could elaborate recommendations on how the government could deal with these and other issues efficiently.

Finally, the question about the possible role of a Border Studies scholar in contributing to practice can be also considered, though there is virtually no contemporary detailed research on this topic. As Kevin Ward argues (2007), there are three major ways in which a geographer could actively participate in promoting social change: policy geography (research aimed at influencing policy-making process), activist geography (research supporting public activism), and participatory geography (research involving "researched" groups as equal partners). While Border Studies scholars also probably could adopt these patterns, conceptualizing the ways in how it could be done would be useful. What is the range of stakeholders to be addressed by policy-oriented research on borders? How to better reach them? What are the ways in which a researcher can contribute to fostering and supporting border-related activism? How and on what basis could equal partnerships between a researcher and "researched" groups (i.e., immigrants, cross-border entrepreneurs, or tourists) be established? These questions await further investigations. 


\section{Conclusion}

During the last decades, Border Studies has managed to overcome its marginal position and become integrated into mainstream social research, but has largely lost its applied character. Indeed, while earlier it helped practitioners to delimit borders and later improve cross-border cooperation, now it largely concentrates on analyzing the very essence of borders and of other relevant phenomena. That is not to say that Border Studies does not pay attention to practically important issues, but now in most cases, analyzing such issues results in destructive criticism of the existing order without proposing viable and well-elaborated solutions.

However, to make contemporary Border Studies more practically relevant, one should not necessarily abandon the existing mainstream approaches as they have significant, though still insufficiently-explored, practical potential. In particular, such approaches can be useful for solving such urgent problems as cross-border region building; applying, optimizing, or dismantling "imaginary" borders in the framework of border policies; managing cross-border conflicts and reducing alarmist perceptions of the Other; fighting border-related injustices and human rights violations; finding efficient strategies of resistance to such injustices and violations, etc. One should not forget about some previous but still relevant approaches that could help to solve delimitation problems, increase efficiency of cross-border cooperation, or to better balance the priorities of strengthening border security and fostering cross-border interactions. Of course, it is not an exhaustive range of border-related problems and approaches for solving them; for instance, drawing new ideas from Management Studies and Communication Studies looks potentially promising. It is also important that the aforementioned approaches, while being applied as practical tools, should not be needlessly considered as mutually exclusive as, at least in some cases, their joint application could bring more fruitful results than applying them separately.

\section{References}

Aas K. F. (2011) "Crimmigrant" bodies and bona fide travelers: surveillance, citizenship and global governance. Theoretical Criminology, vol. 15, no 3, pp. 341-346.

Ackleson J. (2009) From "thin" to "thick" (and back again?): the politics and policies of the contemporary US-Canada border. American Review of Canadian Studies, vol. 39, no 4, pp. 336-351.

Agamben G. (1998) Homo Sacer: Sovereign Power and Bare Life, Stanford: Stanford University Press.

Agamben G. (2005) State of Exception, Chicago: University of Chicago Press.

Albert M. (1999) On boundaries, territory and postmodernity: an international relations perspective. Boundaries, Territory and Postmodernity (ed. D. Newman), London: Frank Cass, pp. 53-68. 
Amoore L. (2013) The Politics of Possibility: Risk and Security Beyond Probability, Durham: Duke University Press.

Andreas P. R. (1999) Sovereigns and Smugglers: Enforcing the U.S.-Mexico Border in the Age of Economic Integration (PhD Thesis), Ithaca: Cornell University.

Andreas P. (2009) Border Games: Policing the U.S. - Mexico Divide, Ithaca: Cornell University Press.

Aron R. (1984) Paix et guerre entre des nations, Paris: Calmann-Lévy.

Association of European Border Regions (n.d.) Cross-border co-operation in Europe. Available at: http://www.aebr.eu/en/members/map_of_members.php (accessed 10 August 2014).

Baert P. (2005) Philosophy of the Social Sciences: Towards Pragmatism, Cambridge: Polity Press.

Balibar É. (2002) Politics and the Other Scene, London: Verso.

Balibar É. (2004) We, the People of Europe?: Reflections on Transnational Citizenship, Princeton: Princeton University Press.

Bigo D. (2005) Policing in the name of freedom. Controlling Frontiers: Free Movement Into and Within Europe (eds. D. Bigo, E. Guild), Aldershot: Ashgate, pp. 1-13.

Bigo D. (2008) EU police cooperation: national sovereignty framed by European security? Security versus Justice?: Police and Judicial Cooperation in the European Union (eds. E. Guild, F. Geyer), Ashgate: Aldershot, pp. 91-108.

Bigo D. (2014) The (in)securitization practices of the three universes of EU border control: Military/Navy-border guards/police—database analysts. Security Dialogue, vol. 45, no 3, pp. 209-225.

Bigo D., Guild E. (2005) Policing at a distance: Schengen visa policies. Controlling Frontiers: Free Movement Into and within Europe (eds. D. Bigo, E. Guild), Aldershot: Ashgate, pp. 233-263.

Bröker J. (1984) How do international trade barriers affect interregional trade? Regional and Industrial Theories (eds. A. E. Andersson, W. Isard, T. Puu), Amsterdam: NorthHolland, pp. 219-239.

Brunet-Jailly E. (2006) Security and border security policies: perimeter or smart border?: a comparison of the European Union and Canadian-American border security regimes. Journal of Borderlands Studies, vol. 21, no 1, pp. 3-21.

Buzan B., Waever O., de Wilde J. (1998) Security: A New Framework for Analysis, Boulder: Lynne Rienner Publishers.

Côté-Boucher K. (2008) The diffuse border: intelligence-sharing, control and confinement along Canada's smart border. Surveillance \& Society, vol. 5, no 2, pp. 142-165.

Diez Th. (2003) Borders: from maintaining order to subversion. New Frontiers of Europe: Opportunities and Challenges (eds. I. Busygina, O. Potemkina), Moscow: MGIMO University, pp. 131-134.

Europa.eu (2013) "Smart Borders": for an open and secure Europe. Available at: http:// europa.eu/rapid/press-release_MEMO-13-141_en.htm (accessed 10 August 2014).

Fawcett C. B. (1918) Frontiers: A Study in Political Geography, Oxford: Clarendon Press. 
Foucher M. (1988) Fronts et frontières: un tour du monde géopolitique, Paris: Fayard.

Giersch H. (1949) Economic union between nations and the location of industries. Review of Economic Studies, vol. 17, no 2, pp. 87-97.

Golunov S. (2008) Faktor bezopasnosti v politike Rossii $i$ Kazahstana po otnosheniyu $k$ ih obshchey granitse [Security as a Factor of Russia's and Kazakhstan's Policies towards the Common Border] (Doctor of Political Sciences' Thesis), Nizhny Novgorod: Nizhny Novgorod State University.

Golunov S. (2012) EU-Russian Border Security: Challenges, Perceptions and Responses, London: Routledge.

Golunov S. (2013) EU-Russian border crossing: the dialogical perspective. Geopolitics, vol. 18, no 4, pp. 933-953.

Golunov S. (2014) Border fences in the globalizing world: beyond traditional geopolitics and post-positivist approaches. Borders, Fences, and Walls: State of Insecurity? (ed. E. Vallet), Aldershot: Ashgate, pp. 117-130.

Hansen N. (1981) The Border Economy: Regional Development in the Southwest, Austin: University of Texas Press.

Haushofer F. (1939) Grenzen in ihrer geographischen und politischen Bedeutung, Heidelberg, Berlin, Magdeburg: Vowinckel.

Henrikson A. K. (2000) Facing across borders: the diplomacy of Bon Voisinage. International Political Science Review, vol. 21, no 2, pp. 121-147.

Herz J. (1957) Rise and demise of the territorial state. World Politics, vol. 9, no 4, pp. 473493.

Holdich T. H. (1916) Political Frontiers and Boundary-Making, London: Macmillan and Co.

House J. (1982) Frontier on the Rio Grande. A Political Geography of Development and Social Deprivation, Oxford: Clarendon Press.

Joenniemi P. (2000) Kaliningrad, borders and the figure or Europe. The EU and Kaliningrad: Kaliningrad and the Impact of EU Enlargement (eds. J. Baxendale, S. Dewar, D. Gowan), London: Federal Trust, pp. 157-176.

Joenniemi P. (2008) Border issues in Europe's North. The European Union and Border Conflicts: The Power of Integration and Association (eds. Th. Diez, M. Albert, S. Stetter), Cambridge: Cambridge University Press, pp. 129-172.

Jones R. (2012) Spaces of refusal: rethinking sovereign power and resistance at the border. Annals of the Association of American Geographers, vol. 102, no 3, pp. 685-699.

Kymlicka W. (2001) Territorial boundaries: a liberal egalitarian perspective. Boundaries and Justice: Diverse Ethical Perspectives (eds. D. Miller, S.H. Hashmi), Princeton: Princeton University Press, pp. 249-275.

Latham R. (2010) Border formations: security and subjectivity at the Border. Citizenship Studies, vol. 14, no 2, pp. 185-201.

Legislationline (2001) US and Canada Smart Border Declaration. Available at: http:// www.legislationline.org/documents/id/7543 (accessed 10 August 2014). 
Lord Curzon (1907) Lecture on the subject of frontiers. Available at: http://www.dur. ac.uk/resources/ibru/resources/links/curzon.pdf (accessed 10 August 2014).

Lyde L.W. (1915) Some Frontiers for Tomorrow: An Aspiration for Europe, London: A.C. Black.

Lyon D. (2003) Surveillance after September 11, Cambridge: Polity Press.

MacPherson A., McConnell J., Vance A., Vanchan V. (2006) The Impact of U.S. government antiterrorism policies on Canada-U.S. cross-border commerce: an exploratory study from Western New York and Southern Ontario. Professional Geographer, vol. 58 no 3, pp. 266-277.

Martinez O. J. (1994) Border People: Life and Society in the U.S.-Mexico Borderlands, Tuscon: The University of Arizona Press.

Ministry of Foreign Affairs of the Russian Federation (2013) O deyatel'nosti i perspektivah razvitiya evroregionov s uchastiyem Kaliningradskoy oblasti [About Activities and Development prospects of Those Regions in which Kaliningrad Province Participates]. Available at: http://goo.gl/EhpvV6 (accessed 10 August 2014).

Morehouse B. (2006) Theoretical approaches to border spaces and identities. Challenged Borderlands: Transcending Political and Cultural Boundaries (eds. V. Pavlakovich-Kochi, B. Morehouse, D. Wastl-Walter), Aldershot: Ashgate, pp. 19-39.

Noborder Network (n.d.) Availabe at: http://www.noborder.org (accessed 10 August 2014).

O’Dowd L. (2010) From a "borderless world" to a "world of borders": bringing history back in. Environment and Planning D: Society and Space, vol. 28, no. 6, pp. 1031-1050.

Ohmae K. (1995) The End of the Nation State: The Rise of Global Economy, London: Harper Collins.

Paasi A. (1996) Territories, Boundaries and Consciousness: The Changing Geographies of The Finnish-Russian Border, Chichester: John Wiley.

Paasi A. (1999) Boundaries as social practice and discourse: the Finnish-Russian border. Regional Studies, vol. 33, no 7, pp. 669-680.

Peirce C. S. (1992) The Essential Peirce: Selected Philosophical Writings, Vol. 1: 1867-1893, Bloomington: Indiana University Press.

Petras E. (1996) The role of national boundaries in a cross-national labour market. The Sociology of Migration (ed. R. Cohen), Cheltenham: Edward Elgar, pp. 494-531.

Pratt A. (2010) Between a hunch and a hard place: making suspicion reasonable at the Canadian border. Social \& Legal Studies, vol. 19, no 4, pp. 461-48o.

Prescott J. R. V. (1965) The Geography of Frontiers and Boundaries, London: Hutchinson University Library.

Prescott J. R. W. (1978) Boundaries and Frontiers, Totowa: Rowman \& Littlefield.

Rumford Ch. (2008) Introduction: citizens and borderwork in Europe. Space and Polity, vol. 12 no 1, pp. 1-12.

Rumford Ch. (2013) Towards a vernacularized border studies: the case of citizen borderwork. Journal of Borderlands Studies, vol. 28, no 2, pp. 169-18o. 
Salter M. (2008) When the exception becomes the rule: borders, sovereignty, and citizenship. Citizenship Studies, vol. 12 no 4, pp. 365-38o.

Salter M. (2013) To make move and let stop: mobility and the assemblage of circulation. Mobilities, vol. 8 no 1, pp. 7-19.

Steiner H. (2001) Hard borders, compensation, and classical liberalism. Boundaries and Justice: Diverse Ethical Perspectives (eds. D. Miller, S. H. Hashmi), Princeton: Princeton University Press, pp. 79-88.

Stoddard E. R. (2002) U.S.-Mexico Borderlands Studies: Multidisciplinary Perspectives and Concepts, El Paso: The Promontory.

Van Houtum H. (2010) Human blacklisting: the global apartheid of the EU's external border regime. Environment and Planning D: Society and Space, vol. 28, no 6, pp. 957-976.

Van Houtum H., Kramsch O., Zierhofer, W. (2003) B/ordering Space. B/ordering Space (eds. H. van Houtum, O. Kramsh, W. Zierhofer), Aldershot: Ashgate, pp. 1-13.

Vaughan-Williams N. (2009) Border Politics: The Limits of Sovereign Power, Edinburgh: Edinburgh University Press.

Vukov T., Sheller M. (2013) Border work: surveillant assemblages, virtual fences, and tactical counter-media. Social Semiotics, vol. 23, no 2, pp. 225-241.

Ward K. (2007) Geography and public policy: activist, participatory, and policy geographies. Progress in Human Geography, vol. 31, no 5, pp. 695-705.

Wolfers A. (1962) Essays on International Politics, Baltimore: The Johns Hopkins Press.

Wonders N.A. (2006) Global flows: semi-permeable borders and new channels of inequality. Borders, Mobility and Technologies of Control (eds. Sh. Pickering, L. Weber), Dordrecht: Springer, pp. 63-86.

Zelionka J. (2001) How new enlarged borders will reshape the European Union. Journal of Common Market Studies, vol. 39, no 3, pp. 507-536.

Zureik E., Salter B. (eds) (2005) Global Surveillance and Policing: Borders, Security, Identity, Portland: Willan Publishing.

\section{Практическая значимость как проблема современных исследований границ}

\section{Сергей Голунов}

Профессор Университета Хоккайдо

Адрес: Nishi 7, Kita 9, Kita-ku, Sapporo, 060-0809, Japan

E-mail: sgolunov@mail.ru

Связанные с границами практические проблемы имеют самое серьезное значение для огромного количества людей. Несмотря на это, нынешние мэйнстримные исследования границ (в которых доминируют постмодернистские, конструктивистские и критические подходы) сосредоточены в основном на концептуализации сущности феномена границ и 
пограничных процессов, но не на поиске реалистичных практических решений упомянутых проблем. Следует отметить, что на более ранних стадиях своего развития исследования границ, напротив, были в значительной степени практически ориентированной дисциплиной, уделявшей особое внимание изучению вопросов делимитации границ, урегулирования пограничных конфликтов, развития приграничного сотрудничества и т.п. В настоящей работе рассматриваются современные теоретические подходы к изучению границ сквозь призму практического потенциала этих подходов, а также анализируются некоторые другие возможности повысить степень практической ориентированности дисциплины. Делается вывод о том, что как традиционные, так и современные подходы обладают значительным практическим потенциалом, который может, в числе прочего, оказаться полезным для решения проблем, связанных с делимитацией, повышением эффективности приграничного сотрудничества, нахождением оптимального баланса между контролем над границей и обеспечением ее проницаемости, урегулированием пограничных конфликтов и смягчения негативных восприятий сопредельной стороны, противодействием ущемлению интересов и нарушениям прав пересекающих границу людей и т.п. Помимо этого, автор полагает, что исследования границ в перспективе могли бы почерпнуть новые практически ориентированные идеи из таких дисциплин, как менеджмент и коммуникативные исследования.

Ключевые слова: исследования границ, пограничная безопасность, конструктивизм, критические исследования, приграничное сотрудничество, постмодернизм, практика, прагматизм 